\title{
Development of Learning Methods for Student Center Learning with Problem Based Learning Through Blended Learning in Block 6.C Infection and Neoplasms of the Reproductive and Breast System
}

\author{
Yulizawati $^{1, *}$ Miranie Safaringga ${ }^{2}$ \\ ${ }^{1}$ Undergraduate Midwifery Program, Faculty of Medicine Andalas University, Jl. Niaga No.156, Belakang Pondok, \\ Padang, West Sumatra 25134, Indonesia \\ *Corresponding author.Email: yulizawati@med.unand.ac.id, miraniesafaringga@med.unand.ac.id
}

\begin{abstract}
Achievement of the learning objectives of a student with the method of learning problem based learning (PBL), can be influenced by the results of extracting their peer information in small groups because the information obtained by students will be discussed to perfect the knowledge gained. This study applies a blended learning and tutorial in the PBL method. The results of the study, there was an increase in the value of students before and after treatment with a value of $p=0,000$, and there was a difference in grades of students in 2017 and 2016, where the grades of students in 2017 were better than in 2016, with $\mathrm{p}=0.001$. The results of the interview that students prefer the Blended Learning method over discussion in large classes, students feel better understand the discussion material, each group member is more active and gives their opinions according to the theory of the book or journal that has been studied, lecturer attention to each student is greater, so students are very enthusiastic in studying the material and discussing it. PBL method with blended learning is very effective to be applied in learning to increase the activeness, interactive, learning motivation, and critical thinking of students.
\end{abstract}

Keywords: Learning methods, Problem based learning

\section{INTRODUCTION}

Block 6.C, entitled Infection and neoplasms of the reproductive system and breast, is a block that must be studied by semester VI students in the Midwifery Study Program, Faculty of Medicine, Andalas University. Learning in this block gives students the opportunity to understand concepts, infections and neoplasms of the reproductive system and breasts. By understanding this concept students are expected to be able to manage midwifery care for infections and neoplasms of the reproductive system and breasts in accordance with the midwife's authority. Thus mastery of the material in Block 6.C is important, because it will provide provisions for students in providing care for infections and neoplasms of the reproductive system and breast.

Learning is prepared in the form of lectures by experts in the appropriate fields, tutorial discussions, and skills training in the laboratory. This block runs for 5 weeks, each module will be discussed every week, so this block will discuss 5 modules. In addition to expert lectures, students will carry out clinical skills training. Every week there will be a plenary discussion on the topic adjusted to the lecture and tutorial material. At the end of the block, the 6.C block theory learning evaluation will take the form of a written test.

The contribution of this block to the competencies /learning outcomes in the curriculum of the study program is that students are able to master 29 main competencies, 9 supporting competencies and 1 specific competency as a midwife who is spread in 7 (seven) Midwife competency areas.

The existing teaching materials developed so far have been in the form of powerpoints, study of journals about childbirth and childbirth and in 2019 it 
is planned to be developed in the form of textbooks supplemented with evidence based practice in childbirth and childbirth.

\section{RESEARCH METHODS AND DEVELOPMENT OF LEARNING METHODS}

The research sample was all female students of the Midwifery Faculty of Medicine, Andalas University 2017, year semester IV semester IV. This research uses quasi- experimental with pretest posttest control group design.

\subsection{Development of problem-based Learning Methods (PBL)}

Problem-based learning (problem-based learning / PBL) is a learning strategy for students learning together in a small group through two main learning activities, namely small group discussions facilitated by a tutor and independent learning.

PBL is a form of student center learning (SCL) learning method that is more directed and structured. In contrast to pure SCL, students are given the discretion in determining the scope of material learned in accordance with their interests. In PBL learning the scope of learning is more focused and specific. The scope of learning in PBL is based on specific learning objectives detailed in the curriculum. The amount of time spent on the PBL process is also more limited than the amount of time spent on pure SCL. In pure SCL, students are given the discretion in determining the amount of time they need to complete their inquiry, while in PBL students must complete the achievement of their learning goals within the time frame determined by the educational institution. In pure SCL, students can work individually based on their respective interests, so they are not dependent on the learning outcomes of other students. Whereas in PBL, the achievement of learning objectives by a student, can be influenced by the results of extracting their peer information in small groups because the information obtained by each student will be discussed to perfect the knowledge they have gained.

Problem solving is not the only goal of the PBL process. Problems or scenarios are used as stimulus learning processes to increase knowledge and understanding of learning goals that have been set in the curriculum. So PBL can also be used to facilitate students in gaining basic knowledge. Thus, PBL not only facilitates the acquisition of problem solving skills, but also the acquisition of knowledge and understanding, and several other soft skills such as communication skills, teamwork, independence and responsibility for learning, sharing information and respecting others.

Planning: a. The lecturer identifies, sets, and groups learning objectives that will be discussed at each PBL learning session.

b. The lecturer arranges, chooses or looks for the right scenario to stimulate students to learn the learning objectives that have been set for each PBL session. Scenarios can be in the form of cases, fragments of films, images, news footage and others.

c. The lecturer estimates the schedule for implementing the 1st PBL tutorial, the amount of independent learning time needed to achieve all the learning objectives that have been set for the PBL session and the schedule for the 2nd PBLtutorial.

d. The lecturer prepares a rubric for evaluating student activities during the tutorial process which consists of attendance, creativity, relevance, attitudes and other assessment points that are deemed necessary.

e. The lecturer divides students into small groups that can consist of 5-10 students per group, each group ideally being facilitated by a tutor.

f. PBL tutors don't have to be lecturers in related fields discussed in the scenario. PBL tutors can be anyone who can carry out the roles, with the following roles:

1) Help PBL group leaders maintain group dynamics.

2) Ensuring the group is able to complete the learning objectives that have been set.

3) Ensure that all students have done their assignments correctly.

4) Helps suggest a format for presentations of independent learning outcomes that is appropriate for group members.

5) Encourage students to evaluate their understanding of the material by asking questions, explaining the material in their own words with pictures and schematics.

6) Give feedback to students about their participation in the tutorial process and about achieving learning objectives.

\subsection{Implementation}

PBL tutorials are carried out in various ways. The PBL model in the Midwifery Study Program at the Faculty of Medicine at Andalas University is seven jumps. For each module, students can be given a handbook containing scenarios, while learning resources or materials are given at the right time according to the progress of the tutorial. The steps for implementing PBL are as follows:

a. Students are allowed to choose seats to sit on chairs that have been arranged in such a way that 
facilitates group discussion.

b. Students choose a group leader who will act as the moderator of the discussion, and two clerks to record the discussion on a sheet of paper and on the board. The role is played for each scenario. The appropriate flip chart or whiteboard must be used to record the discussion process.

c. At the beginning of the session, depending on the type of scenario, one student reads the scenario to all group members or each student the scenario individually. If the trigger or scenario is a real patient in the ward, clinic or operating room then students may be asked to take a clinical history or identify abnormal physical signs before the group meves to the tutorial room. The stages of seven jumps are as follows :

Step 1: Identifying and explaining incomprehensible terms encountered in the scenario, the scribe notes a list of terms that remain in application after discussion.

Step 2: Defining the problem or problem to be discussed, students may have different views about the problem, but all must be considered, the scribe notes the agreed list of problems.

Step 3 : "Brainstorming" is a session to discuss issues.

Step 4: Review the discussion reviews in steps 2 and 3. Then organize the explanation into a tentative solution, which is restructured in the form of a scheme.

Step 5: Formulate learning objectives, the group reaches consensus on learning objectives, the tutor ensures that learning objectives are focused, attainable, comprehensive and appropriate.

Step 6: Self study. All students gather information related to each learning goal. This step is done outside of the PBL tutorial. Lecturers or tutors need to give sufficient time for students to do independent learning so that all learning objectives are achieved.

Step 7: The group will gather again for discussion (2nd tutorial discussion). Students share and discuss their independent learning outcomes. Tutors evaluate student learning outcomes.

\subsection{Development of Student Assessment}

Development of student assessment systems which include: Process assessment, Result assessment, Selection of assessment techniques according to competency level.

\section{RESULTS AND DISCUSSION}

Table 1. Comparison of 2016 and 2017 students' knowledge

\begin{tabular}{|c|c|c|c|c|c|}
\hline \multirow[t]{2}{*}{$\begin{array}{l}\text { Value } \\
\text { Range }\end{array}$} & \multicolumn{2}{|c|}{$\begin{array}{c}\text { Force } \\
2016 \\
\end{array}$} & \multicolumn{2}{|c|}{$\begin{array}{c}\text { Force } \\
2017\end{array}$} & \multirow[t]{2}{*}{$\begin{array}{c}P \\
\text { Value }\end{array}$} \\
\hline & $\mathbf{F}$ & $\%$ & $\mathbf{F}$ & $\%$ & \\
\hline $85-100$ & 0 & 0 & 0 & 0 & \\
\hline $80-84$ & 0 & 0 & 0 & 0 & \\
\hline $75-79$ & 33 & 6 & 7 & 16 & \\
\hline $70-74$ & 12 & 23 & 19 & 42 & \\
\hline $65-69$ & 22 & 42 & 17 & 38 & 0.001 \\
\hline $60-64$ & 10 & 19 & 1 & 2 & \\
\hline $55-59$ & 3 & 6 & 0 & 0 & \\
\hline $50-54$ & 2 & 4 & 1 & 2 & \\
\hline
\end{tabular}

Table 2. Comparison of 2017 students' knowledge between before and after class action research (CAR)

\begin{tabular}{|c|c|c|c|c|c|}
\hline \multirow{2}{*}{$\begin{array}{l}\text { Value } \\
\text { Range }\end{array}$} & \multicolumn{2}{|c|}{ Pretest } & \multicolumn{2}{|c|}{ Posttest } & \multirow{2}{*}{$\begin{array}{c}\mathbf{P} \\
\text { Value }\end{array}$} \\
\hline & $\mathbf{F}$ & $\%$ & $\mathbf{F}$ & $\%$ & \\
\hline $85-100$ & 0 & 0 & 0 & 0 & \\
\hline $80-84$ & 1 & 2 & 9 & 20 & \\
\hline $75-79$ & 1 & 2 & 16 & 36 & \\
\hline $70-74$ & 6 & 13 & 14 & 31 & \\
\hline $65-69$ & 8 & 18 & 4 & 9 & 0.000 \\
\hline $60-64$ & 5 & 11 & 1 & 2 & \\
\hline $55-59$ & 9 & 20 & 0 & 0 & \\
\hline $50-54$ & 15 & 33 & 1 & 2 & \\
\hline
\end{tabular}

The calculation results show that the majority of students in 2016 have a range of values between 65 $95,42 \%$ of 53 people. Then the same research was conducted on the 2017 class of students, it was found that the majority of students had a range of 70-74, which was $42 \%$ of 45 people.

The condition will cause students to be less active and creative in developing and exploring learning from various sources. The implication is that graduates who are formed will not be independent and confident because they feel dependent on learning activities that are based solely on lecturers (Widiara, 2019).

Furthermore, in the research journal Annisa Ratna Sari (2013) stated that other impacts of the use of classical learning concepts with the lecture method will cause students' Critical Thinking abilities to be less honed because students are not accustomed to thinking outside the context conveyed by the lecturer and become passive in choosing additional learning resources outside of the learning resources provided by the lecturer. Therefore, blended learning learning strategy is one alternative in improving student learning outcomes.

The combination of classical learning added with the use of the internet is a supplement in increasing student achievement. This is because pedagogy is better produced, increased access and flexibility, and increased cost of benefits (Annisa, 2013: 34).

The addition of learning innovations will arouse the independence and confidence of students who 
have tried to find and explore learning resources not only from lecturers. Independence of students plays an important role in learning success.

Sandi (2012) states, students who have high independence excel in blended learning that is more student-centered. Therefore, increasing the independence of students is a critical in improving learning outcomes that need attention of lecturers and other educational researchers.

Various studies also show that blended learning is more effective compared to conventional learning with face-to-face systems as well as with elearning systems or online learning. The level of effectiveness is supported by the advantages possessed by blended learning, as follows:

a. Delivery of learning can be carried out anytime and anywhere by utilizing an internet network system.

b. Learners have the flexibility to study material or teaching materials independently by utilizing teaching materials stored online.

c. Discussion activities take place online / offline and take place outside of class hours, discussion activities take place both between students and lecturers and between students themselves.

d. Teachers can manage and control the learning done by students outside of student learning hours.

e. Teachers can ask students to review the subject matter before face-to-face learning takes place by preparing supporting tasks.

f. The achievement target of teaching material can be achieved according to the target set

g. Learning becomes flexible and not rigid

Of course, learning with the concept of combination / assimilation in addition to having the advantages above also has shortcomings, including:

a. Teachers need to have skills in organizing elearning

b. Teachers need to prepare time to develop and manage learning elearning systems, such as developing material, preparing assessments, conducting assessments, and answering or giving statements at forums that are delivered by students.

c. Teachers need to prepare digital references as students' references and digital references that are integrated withface- to-face learning

d. Unequal supporting facilities and infrastructure and low understanding of technology.

e. Learning strategies are needed by instructors to maximize the potential of blended learning

In a study conducted by Mangg Stephani in 2016, learning using the blended learing method was proven to increase student motivation in SMAN 1 Patakatua Wajo District with the results of descriptive analysis of student motivation, it was found that the average score of students' motivation from each positive and negative statement in the experimental class who use Blended Learning learning model that is 3.4 higher than the average score of student motivation in the control class that uses direct learning that is 2.7. This shows that the motivation of students in the control class is lower compared to the experimental class. High or low student motivation also affects student learning outcomes or learning achievement.

Based on the results of the discussion above it can be concluded that blended learning has a positive impact on increasing the value and motivation of student learning in Block $6 \mathrm{C}$.

\section{CONCLUSION}

a. Based on the results of the discussion above it can be concluded that blended learning has a positive impact on increasing the value and motivation of student learning in Block 6C.

b. In the assessment, with the integration of knowledge assessment, there was an increase in the 2017 Force $6 \mathrm{c}$ Block.

c. In the assessment before and after the action, obtained an increase in the value of knowledge between before and after treatment.

\section{AUTHORS' CONTRIBUTIONS}

The author's contribution are to play a role in curriculum development, curriculum revision, and improvement of graduate outcomes.

\section{ACKNOWLEDGMENTS}

Alhamdulillah, praise be to the presence of Allah SWT who Most Merciful and Most Compassionate for mercy and His grace so that researchers can complete this research on time.

\section{REFERENCES}

[1] Lutfiasari D \& Prasetyanti DK. 2016. The Use of Problem Based Learning Method Against Partograph Filling Skills in Semester III Students in Midwifery Study Program (D III) Kadiri University.

[2] Renityas, NN. 2015. The Effectiveness of Problem Based Learning Models Against the Level of Learning Participation in Pregnancy Midwifery Care Courses in the Diploma Program. Nursing and Midwifery Journal, Volume 2, No.1, April 2015. DOI: 10.26699 / Inj.v2i!.ART.p092094. 
[3] Daryanto 2014. Scientific Learning Approach for Curriculum 2013. Yogyakarta: Gava Media.

[4] Hosnan 2014. Scientific and Contextual Approaches in 21st Century Learning The Key to Successful Implementation of the 2013 Curriculum. Jakarta: Ghalia Indonesia.

[5] Sanjaya, Vienna. 2006. Learning Process Oriented Education Standard Process. Jakarta: Kencana Prenada Media Group.

[6] Azizah, SUN. 2017, The Effectiveness of Small Group Discussion Learning Strategies on Student Learning Achievement in the Subjects of Pie Class VIII in Negeri 27 Surakarta in 2016/2017 Academic Year. Thesis. Islamic Religious Studies Program, Faculty of Tarbiyah and Teacher Training, Surakarta State Islamic Institute.

[7] Bahri, Syaiful et al. 2010. Teaching and Learning Strategies. Jakarta: Rineka Cipta.

[8] Sharmila SR, Mungal SU, More SR. Developing competencies of medical students using group discussion as TL method. IOSR J Dent Med Sci. 2014; 13: 24-7.

[9] Sajjad S. Effective teaching methods at higher education levels. Mr. J Spec Educ. 2010; 11: 29-43.

[10] Gopalakrishnan P, Swati Patki, Varghese SS, Harsha CH, Antony R. Effectiveness of different methods of education among first year medical 6 students in Central Kerala. Int J Med Pharm Sci. 2014; 5: 01-4.

[11] Annamalai N, Manivel R, and Palanisamy R. 2015. Small group discussion: Students perspectives. Int J Appl Basic Med Res. 2015 Aug; 5 (Suppl 1): S18 - S20. doi: 10.4103 / 2229-516X.162257. PMCID:

PMC4552057. PMID: 26380202.

[12] Sood R, Adkoli BV. Medical education in India Problems and prospectus. J Indian Acad Clin Med. 2000; 1: 210-2.

[13] Medical Council of India. Vision. 2015. [Last accessed on 2012Jan 07]. Available from: http://www.mciindia.org/tools/announcement/MCI- 